\title{
Frugal Innovation: origins, evolution and future perspectives
}

\section{Graziele Ventura Koerich ${ }^{1}$ Éverton luís Pellizzaro de Lorenzi Cancellier ${ }^{1}$}

\author{
${ }^{1}$ UniVERsidade de SANTA CATARINA (UFSC) / CENTRO de CiÊnCIAS dA AdMINISTRAÇÃo E \\ Socioeconômicas, Programa de Pós-Graduação em Administração, Florianópolis - SC, Brazil
}

\begin{abstract}
Frugal innovation has recently become a relevant topic in social and academic discourse. The real challenge for this new manifestation of innovation is the introduction of something new or different with the use of few resources. Frugal innovations have generally been associated with emerging economies where large consumer groups are at the bottom of the pyramid with unmet needs. However, there is growing evidence that this phenomenon is also becoming relevant in industrialized nations, potentially affecting the long-term competitiveness of domestic enterprises, not only abroad but also locally. Consequently, frugal innovation scholars have begun to investigate attempts to systematize this emerging field of research and promote the development of this debate. This theoretical study presents the origin and evolution of the frugal innovation approach and its current characterization in the literature; discusses future perspectives on the topic; and suggests that future works invest in empirical research, enriching existing debates on frugal innovation, especially from the lens of local economic development, through financial results and economic returns. It also reinforces the need to develop frugal innovation measurement instruments.
\end{abstract}

Keywords: Frugal Innovation. Emerging Markets. Frugality. Innovation.

\section{Inovação Frugal: origens, evolução e perspectivas futuras}

\section{Resumo}

A inovação frugal tornou-se recentemente um tópico relevante no discurso social e acadêmico. O verdadeiro desafio para essa nova manifestação de inovação caracteriza-se pela introdução de algo novo ou diferente com uso de poucos recursos. As inovações frugais têm ocorrido, em geral, associadas a economias emergentes nas quais se encontram grandes grupos de consumidores na base da pirâmide com necessidades não atendidas. Todavia há evidências crescentes de que este fenômeno está se tornando relevante também nas nações industrializadas, potencialmente afetando a competitividade das empresas domésticas em longo prazo, não apenas no exterior, mas também localmente. Como consequência, os estudiosos da inovação frugal começaram a investigar tentativas de sistematizar esse campo emergente de pesquisa e promover o desenvolvimento desse debate. Desse modo, este ensaio teórico tem por objetivos: apresentar a origem e evolução da abordagem da inovação frugal e sua caracterização atual na literatura; em seguida, discutir perspectivas futuras de estudo no tema; por fim, sugere-se que estudos futuros invistam em pesquisas empíricas, enriquecendo os debates existentes sobre a inovação frugal, principalmente da lente do desenvolvimento econômico local, por meio de resultados financeiros e retornos econômicos. Reforça-se também a necessidade de desenvolvimento de instrumentos de mensuração de inovação frugal.

Palavras-chave: Inovação frugal. Mercados emergentes. Frugalidade. Inovação.

\section{Innovación Frugal: orígenes, evolución y perspectivas futuras}

\section{Resumen}

La innovación frugal se ha convertido recientemente en un tema relevante en el discurso social y académico. El verdadero desafío para esta nueva manifestación de innovación es la introducción de algo nuevo o diferente con el uso de pocos recursos. Las innovaciones frugales generalmente se han asociado con economías emergentes donde grandes grupos de consumidores se encuentran en la parte inferior de la pirámide con necesidades no satisfechas. Sin embargo, hay cada vez más pruebas de que este fenómeno también se está volviendo relevante en los países industrializados, lo que podría afectar la competitividad a largo plazo de las empresas nacionales, no solo en el extranjero sino también a nivel local. Como consecuencia, los estudiosos de la innovación frugal han comenzado a investigar los intentos de sistematizar este campo de investigación emergente y promover el desarrollo de este debate. De este modo, este ensayo teórico pretende: presentar el origen y la evolución del enfoque de la innovación frugal y su caracterización actual en la literatura; luego discutir las perspectivas de estudio futuras sobre el tema. Finalmente, se sugiere que los estudios futuros inviertan en investigación empírica para enriquecer los debates existentes sobre innovación frugal, especialmente desde la perspectiva del desarrollo económico local, a través de resultados financieros y retornos económicos. También se refuerza la necesidad de desarrollar instrumentos de medición de innovación frugal.

Palabras clave: Innovación frugal. Mercados emergentes. Frugalidad. Innovación. 


\section{INTRODUCTION}

Innovation has been widely studied in management literature (CHANDY, HOPSTAKEN, NARASIMHAN et al., 2006; LAFLEY and CHARAN, 2008; VON KROGH and RAISCH, 2009; KULANGARA, JACKSON and PRATER, 2016; WANG and DASS, 2017). For Thompson (1965), innovation is about the conception, acceptance, and implementation of new ideas, processes, products or services. For Crossan and Apaydin (2010), innovation is the production or adoption, assimilation, and exploration of a novelty that adds economic and social value. It is renewing and expanding production, services, and markets, developing new production methods, and establishing new management systems. For the authors, innovation is both a process and an outcome.

Innovation manifests in different ways in different countries, regarding the level of investments, structure, and institutional development (WANG, HONG, KAFOUROS et al., 2012). The emerging low-income markets are examples of these differences, where there are many unmet needs increasingly enabling new sources of innovation (ZESCHKY, WIDENMAYER and GASSMANN, 2011; TIWARI and HERSTATT, 2012; BREM and IVENS, 2013). In practical terms, it means that the focus of innovation and the places it is likely to occur are changing. There is an urgent need to improve the theories, models, and framework on innovation management (SIMULA, HOSSAIN and HALME, 2015).

Based on the 'structured innovation' that emerged in the US after World War II, innovation is defined as a system consisting of input and control of resources, processes, and outputs. Therefore, the more resources used, the more innovations are obtained as outputs (MAZIERI, 2016). Considering the distance between rich and emerging countries, as well as the absence of substantial financial investments, structured innovation flows from a 'parent' or center organization to its subsidiaries, or the developed to the emerging markets (GOVINDARAJAN and TRIMBLE, 2012). However, some innovations do not reproduce this flow, obtaining commercial success and market scale in their original emerging market, serving thousands of disadvantaged people (CRISP, 2014). Thus, there are other forms of innovation underway in emerging markets that are not sufficiently explained in the framework of the structured innovation, as these new innovative solutions are produced in contexts of institutional, resource, and infrastructure constraints. (MAZIERI, 2016).

These new forms of innovation appear responding to unattended needs of potential customers, those who have been neglected by regular businesses because of their low purchasing power and distinct needs (ZESCHKY, WIDENMAYER and GASSMANN, 2011; TIWARI and HERSTATT, 2012; BREM and IVENS, 2013). In this sense, frugal innovation is an emerging paradigm that promotes (re)design of products and services to serve low to middle-income consumers (SIMULA, HOSSAIN and HALME, 2015; KNORRINGA, PEŠA, LELIVELD et al., 2016). There is growing evidence that this phenomenon is gaining space in developed and industrialized countries, potentially affecting the long-term competitiveness of their companies, both nationally and internationally (TIWARI and HERSTATT, 2013; ZESCHKY, WINTERHALTER and GASSMANN, 2014; TIWARI, FISCHER and KALOGERAKIS, 2016).

Frugal innovation is socially and academically highlighted (BOUND and THORNTON, 2012; RADJOU and PRABHU, 2014; RAMDORAI and HERSTATT, 2015) in studies on emerging markets strategies. Thus, there is the emergence of different theories: "resource-constrained innovation" (RAY and RAY, 2010), "frugal innovation" (WOOLDRIDGE, 2010; ARGARWAL and BREM, 2012), "frugal engineering" (KRISHAN and DAVIS, 2012), "reverse innovation" (GOVINDARAJAN and RAMAMURTI, 2011; GOVINDARAJAN and TRIMBLE, 2012a); "Disruptive innovation", "cost innovation" (WILLIAMS and VAN TRIEST, 2009), "inclusive innovation" (GEORGE, MCGAHAN and PRABHU, 2012; CHATAWAY, HANLIN and KAPLINSKY, 2014) and "jugaad" (in Hindi) or "creative improvisation" "(GULATI, 2010; RADJOU, PRABHU and AHUJA, 2012; AGARWAL and BREM, 2012; BHATTI and VENTRESCA, 2013; BASU, BANERJEE and SWEENY, 2013; RAO, 2013; HARTLEY, 2014).

For Bhatti and Ventresca (2013), the common ground to all these terminologies is that they draw on the lessons learned from innovations created in emerging and developing markets, increasing the richness of dialogue, even though with variations. Several studies seek to distinguish the nuances of these terms and concepts to have a better idea of frugal innovation (BREM and WOLFRAM, 2014; OSTRASZEWSKA and TYLEC, 2015; WEYRAUCH and HERSTATT, 2016). Bhatti (2012) and Bhatti and Ventresca (2013) observe that scholars have cited various forms of frugal innovation, and often use these variations interchangeably. Despite the increasing number of studies, only a few of them define the concept, even if lacking a theoretical or empirical basis. 
Regarding the growing interest in the subject, several articles have been published in the press highlighting the relationship between innovation and emerging markets (REENA 2009; SARAF, 2009; GOVINDARAJAN and TRIMBLE 2005; CHRISTENSEN, SCOTT and ERIK, 2004). Traditionally, frugal innovation is a topic observed in studies focusing on developing countries. However, it is possible to observe that the phenomenon is gaining space also in advanced economies (PISSONI, MICHELINI and MARTIGNONI, 2018). Some scholars highlight the need to systemize research in this field, identifying the gaps in the literature and a lack of instruments that allow data measurement and quantification (ROSSETTO, BORINI and FRANKWICK, 2018).

This theoretical essay aims to shed light on the origin and evolution of the concept of 'frugal innovation,' examining how it has been characterized in the literature (BREM and WOLFRAM, 2014; HOSSAIN, 2017; WEYRAUCH and HERSTATT, 2016; AGARWAL, GROTTKE, MISHRA et al., 2017; PISSONI, MICHELINI and MARTIGNONI, 2018). Included are suggestions for future research and application. The reflections presented here offer a qualitative analysis both of the evolution of the concept and the conclusions of previous studies on the issue, expanding the understanding of the importance of frugal innovation.

\section{Origins and evolution of the concept}

The notion of 'frugal mindset' has arisen in emerging markets, particularly in India and China, due to extreme adversities and needs in these economies (BHATTI and VENTRESCA, 2013; RADJOU, PRABHU and AHUJA, 2012). Although the issue of 'frugality' has been present in academic discourse for a long time, the term "frugal innovation" is new, appearing in the last years of the past decade. Business magazine The Economist was one of the pioneers combining 'frugality' with 'innovation,' when publishing the article "Health care in India: Lessons from a frugal innovator" (ECONOMIST, 2009; TIWARI, KALOGERAKIS and HERSTATT, 2016).

In the context of these first appearances, 'frugal' is associated with the economy of resources, simplicity, and clarity (MERRIAMWEBSTER, 2015). Scholars - not unanimously - consider India as the leading market for frugal innovation, a genuine "laboratory" (TIWARI and HERSTATT, 2012; PRATHAP, 2014). The concept, however, has been disseminated among organizations that are increasingly aware of the need to innovate with limited resources, to be able to satisfy the needs of low-income consumers at the bottom of the pyramid (RAO, 2013). The work of Pissoni, Michelini and Martignoni (2018) argues that 'frugal' is often seen as an approach (PRABHU and JAIN, 2015; BREM and WOLFRAM, 2014) or a mindset (SONI and KRISHNAN, 2014), rather than a specific form of innovation.

The concept of "frugality" can be a starting point to study the nature of frugal innovations. It is not a new concept, but its association with business models and innovation studies is indeed a new trend of research (SINGH, 2017). It is important to emphasize that, according to Bhatti and Ventresca (2013), the idea that innovation is different in developing and developed countries is not new. The differences are seen in the various terminologies employed when describing innovation in emerging markets. Thus, understanding concepts and terminologies is an essential step towards understanding frugal innovation and its characteristics.

Frugal innovation can also be understood as "jugaad" (creative improvisation) innovation, which requires quick and intelligent adaptation to uncertain circumstances (RADJOU, PRABHU and AHUJA, 2012; BOBEL, 2012; RADJOU and PRABHU, 2014). However, the Hindi term jugaad has a negative connotation among innovation researchers, who consider it to be a simplification that does not represent the main current of thought in the field, focused on the process of innovation (KRISHNAN, 2010; BIRTCHNELL, 2011). For Mazieri (2016), jugaad refers to a solution for resource constraint and contingency. While companies have traditionally focused on structured tools, processes, and techniques for managing innovation, jugaad refers to bottom-up solutions that are less focused on formal innovation processes and more on people and creativity (SIMULA, HOSSAIN and HALME, 2015).

Another terminology related to innovation in emerging markets is the 'frugal engineering,' characterized by Brem and Wolfram (2014, p. 6) as: 
[...] 'ability to absorb, adapt, and build upon the technologies imported from abroad rather than produce completely novel technologies' (KUMAR, 2008, p. 251) to reduce total cost, accelerate product development (REDDY, 2011, p. 1), and deliver value for money (KUMAR, 2008, p. 254). Frugal engineering or constraint-based innovation focuses on awareness and a cognitive approach in developing new products, services, and businesses in constrictive conditions (SHARMA and GOPALKRISHNAN, 2012).

Another similar definition that fits innovation using limited resources is the 'catalytic innovation.' Christensen, Baumann, Ruggles et al. (2006, p. 96) state that social entrepreneurs committed to this type of innovation yearn to expand the social wealth of poor customers by creating "[...] scalable, sustainable, systems-changing solutions." Bhatti and Ventresca (2013) emphasize that, in developed countries, the sustainable provision of basic services to all citizens is increasingly challenging. This context has "[...] put scarcity on the agenda for Western companies, forcing them to find frugal ways to grow with less" (RADJOU, PRABHU and AHUJA, 2012, p. 14). Companies embrace frugality in times of reduced revenue or squeezed profits driven by competitiveness.

Christensen, Baumann, Ruggles et al. (2006) highlight five characteristics of 'catalytic innovators': a) They promote systemic social change by seeking to scale and replicate solutions; b) They meet a need that is overserved (because the existing solution is too complicated) or not served at all; c) They offer low-cost and reduced performance products and services that are good enough to satisfy the customers; d) They explore other types of resources, such as donations, volunteer manpower, or intellectual capital, that are unattractive to competitors; and e) The catalytic innovators are often ignored or underestimated by existing players. Given these characteristics, the analogy between catalytic innovation and frugal innovation is understandable. In the case of catalytic innovation, however, there is an emphasis on small, unnoticed competitors and social change (BREM and WOLFRAM, 2014).

Another term related to the emerging market context refers to the grassroots innovation mentioned in the study by Brem and Wolfram (2014). This form of innovation, created by local people with the resources available and is designed primarily to reduce or eliminate heavy work (GUPTA, 2008). For Brem and Wolfram (2014), grassroots innovation is similar to jugaad. However, the first presents the factors of networking and ecological comprehension not considered in the concept of the second. The authors add that grassroots innovation highlights the issues of corporate social responsibility and the valorization of the creative capacity of low-income people. In this kind of emerging market phenomenon, the advances in grassroots innovations occur, especially in rural areas, where science and political resources rarely arrive. Therefore, the local population is pushed to establish intense communication to supply the scarcity of scientific resources (GUPTA, 1999).

Brem and Wolfram (2014) identify and discuss indigenous innovation. The authors observe that there is little research on the term, focusing on the macroeconomic level, and discussing the inherent difficulty of extending the benefits of international trade to developing countries. Regarding the scenario of international activities of R\&D, indigenous innovation research analyzes technology transfer between organizations in developed and developing countries, observing its effects on domestic economies in developing countries, or the spillover effects (FU and GONG 2011; SCHWAAG SERGER and BREIDNE, 2007; BREM and WOLFRAM, 2014).

In the face of these correlated terms, the frugal innovation has led to a reflection on the nature of innovation as an 'ability to do more with less,' which creates more commercial and social value and minimizes the use of resources such as energy, capital, and time (RADJOU and PRABHU, 2014). For Gupta (2011), frugal innovation refers to a new management philosophy that incorporates the specific needs of the markets at the bottom of the social pyramid as a starting point. It works to develop appropriate solutions that may be significantly different from existing solutions designed to meet the needs of regular market segments. Mazieri, Santos and Quoniam (2014) define that frugal innovation is a response to an observable constricting context, developed with a drastic economy of resources and focusing on the decisive inclusion of the neglected demographic masses.

Finally, another related terminology is reverse innovation, which is often used as a synonym for frugal innovation. Although these terms have similar designations and are interrelated (SIMULA, HOSSAIN and HALME, 2015), there is a difference that distinguishes one from another, characterizing reverse innovation as one that is adopted first in emerging economies, before migrating to rich countries (GOVINDARAJAN and RAMAMURTI, 2011). Nunes and Breene (2011) emphasize that 
frugal innovation is designing solutions targeting low-income market segments. Reverse innovation is developing and selling new products in emerging markets as a first step and then modifying these products to gain market share in developed countries. These definitions give relevant distinction, given that reverse innovation is the main challenge for organizations in developed markets, and observing the growing importance of R\&D in developing markets (AGARWAL and BREM, 2012; SINGHAL, 2011).

In this sense, reverse innovation represents an opposite flow in comparison to the traditional path of the structured innovation, which is based on innovation going from developed to developing countries. Thus, emerging countries are not mere recipients of innovation produced in wealthy nations. Innovation created in the developing world is adopted in developed countries to meet the needs of a particular set of customers, in phenomenon that have caught the attention of numerous researchers (IMMELT, GOVINDARAJAN and TRIMBLE, 2009; RAMAMURTI, 2012; GOVINDARAJAN and RAMAMURTI, 2011; GOVINDARAJAN and TRIMBLE, 2012; HOSSAIN and SIMULA, 2013).

\section{Characteristics of frugal innovation}

The study of the forms of innovations produced in emerging markets reveals that there is no common understanding of the wording used to express frugal innovation and the relationships among the overlapping and sometimes confusing terms. For Brem and Wolfram (2004), this lack of common understanding prevents the academic discussion from advancing and gaining deeper insights based on different perspectives. Against this backdrop, the study by Pissoni, Michelini, and Martignoni (2018) confirms the growing attention of scholars on frugal innovation, based on the recent attempts to systematize the academic contributions on the subject.

In this sense, Box 1 presents the definitions and characteristics of frugal innovation in the literature.

\section{Box 1}

\section{Characteristics and definitions of frugal innovation in literature}

\begin{tabular}{|c|c|c|}
\hline Authors & Definition & Characteristics \\
\hline Gupta (2011) & $\begin{array}{l}\text { New managerial philosophy that includes specific } \\
\text { needs of markets at the base of the social pyramid as a } \\
\text { starting point, and works in a reverse way, i.e., it works } \\
\text { to develop adequate solutions that can be significantly } \\
\text { different from existing solutions. }\end{array}$ & \\
\hline Bhatti (2012) & $\begin{array}{l}\text { "It is not simply about reducing cost, but can also involve } \\
\text { increasing the affordability power of the buyer through } \\
\text { income generation, saving, or alternative payment } \\
\text { schemes. Frugal innovation may also mean that the } \\
\text { outcome involves building local entrepreneurship, } \\
\text { capacity building and self-reliance or sustainability" } \\
\text { (BHATTI, 2012, p. 18). }\end{array}$ & $\begin{array}{l}\text { - Increase accessibility; } \\
\text { - Sustainability. }\end{array}$ \\
\hline $\begin{array}{l}\text { Tiwari and Herstatt } \\
\text { (2012) }\end{array}$ & $\begin{array}{l}\text { "[...] seek to minimize the use of material and financial } \\
\text { resources in the complete value chain (development, } \\
\text { manufacturing, distribution, consumption, and disposal) } \\
\text { with the objective of reducing the cost of ownership } \\
\text { while fulfilling or even exceeding certain pre-defined } \\
\text { criteria of acceptable quality standards" (TIWARI and } \\
\text { HERSTATT, 2012, p. 98). }\end{array}$ & $\begin{array}{l}\text { - Accessibility; } \\
\text { - Robustness; } \\
\text { - Conviviality; } \\
\text { - Scalability; } \\
\text { - Attractive value proposition. }\end{array}$ \\
\hline $\begin{array}{c}\text { Bound and } \\
\text { Thorthon (2012) }\end{array}$ & $\begin{array}{l}\text { It is a distinct innovation approach that responds to } \\
\text { limitations of financial, material, or institutional resources } \\
\text { and transforms this constricts into an advantage. It } \\
\text { opposes the mindset that frugal innovation can be } \\
\text { considered the creation of cheap and low-technology } \\
\text { products. }\end{array}$ & $\begin{array}{l}\text { Four characteristics: } \\
\text { 1) Implies in producing things that are } \\
\text { better and not only cheaper; } \\
\text { 2) It applies to services and products; } \\
\text { 3) Refers to remodeling, not only to } \\
\text { disadvantage; } \\
\text { 4) low-cost does not mean low-tech. }\end{array}$ \\
\hline
\end{tabular}




\begin{tabular}{|c|c|c|}
\hline Authors & Definition & Characteristics \\
\hline $\begin{array}{l}\text { Basu, Banerje and } \\
\text { Sweeny (2013) }\end{array}$ & $\begin{array}{l}\text { Process of design innovation in which citizens' needs and } \\
\text { the context in developing countries are at the center } \\
\text { when developing adequate services and products, } \\
\text { adaptable and accessible for emergent markets. }\end{array}$ & $\begin{array}{l}\text { Robustness; light-weight; solutions suitable } \\
\text { for mobile devices; human-centered } \\
\text { design; simplification; new distribution } \\
\text { models; adaptation; use of local resources; } \\
\text { green technology; accessibility. }\end{array}$ \\
\hline $\begin{array}{l}\text { Pawlowski } \\
\text { (2013) }\end{array}$ & $\begin{array}{l}\text { "Frugal innovation is about creating highly scalable } \\
\text { products, which have reduced functionalities while } \\
\text { reducing costs" (PAWLOWSKI, 2013, p. 527). }\end{array}$ & \\
\hline $\begin{array}{l}\text { Brem and Wolfram } \\
\qquad(2014)\end{array}$ & Derived management approach. & $\begin{array}{l}\text { Sophistication, sustainability, and emerging } \\
\text { markets oriented. }\end{array}$ \\
\hline $\begin{array}{l}\text { Zeschky, } \\
\text { Winterhalter and } \\
\text { Gassmann (2014) }\end{array}$ & $\begin{array}{l}\text { "[...] frugal innovations are not re-engineered solutions } \\
\text { but originally developed products or services for } \\
\text { very specific applications in resource-constrained } \\
\text { environments" (ZESCHKY, WINTERHALTER and } \\
\text { GASSMANN, 2014, p. 23). }\end{array}$ & $\begin{array}{l}\text { Technical novelty and market innovation. } \\
\text { Criteria: the same for less, customized for } \\
\text { less, and new for less. }\end{array}$ \\
\hline $\begin{array}{l}\text { Prabhu and Gupta } \\
\qquad(2014)\end{array}$ & $\begin{array}{l}\text { "Frugal innovations in products are vital in developing } \\
\text { countries to reach price sensitive customers that seek } \\
\text { robust products at low prices" (PRABHU e GUPTA, } \\
2014, \text { p. 3309). }\end{array}$ & - Price sensitive customers. \\
\hline $\begin{array}{l}\text { Radjou and Prabhu } \\
\qquad(2014)\end{array}$ & $\begin{array}{l}\text { The capacity of doing more with less, creating more } \\
\text { commercial and social value, minimizing the use of } \\
\text { resources. }\end{array}$ & $\begin{array}{l}\text { Principles: involve and reiterate, flexible } \\
\text { resources, create sustainable solutions, } \\
\text { mold customer behavior, co-create value } \\
\text { with potential clients, and make innovative } \\
\text { friends. }\end{array}$ \\
\hline $\begin{array}{l}\text { Tiwari and Herstatt } \\
\qquad(2014)\end{array}$ & $\begin{array}{l}\text { Frugal innovation can be characterized as "[...] new } \\
\text { or significantly improved products (both goods and } \\
\text { services), processes, or marketing and organizational } \\
\text { methods that seek to minimize the use of material } \\
\text { and financial resources in the complete value } \\
\text { chain (development, manufacturing, distribution, } \\
\text { consumption, and disposal) with the objective of } \\
\text { significantly reducing the total cost of ownership and/ } \\
\text { or usage while fulfilling or even exceeding certain } \\
\text { pre-defined criteria of acceptable quality standards" } \\
\text { (TIWARI and HERSTATT, 2014, p. 30). }\end{array}$ & $\begin{array}{l}\text { - Minimize the use of material and } \\
\text { financial resources. }\end{array}$ \\
\hline $\begin{array}{l}\text { Soni and Krishnan } \\
\qquad(2014)\end{array}$ & $\begin{array}{l}\text { "Meeting the desired objective with a good-enough } \\
\text { economical means" (SONI and KRISHNAN, 2014). }\end{array}$ & $\begin{array}{l}\text { Frugal innovation may be interpreted as } \\
\text { a mindset or lifestyle, a process, and a } \\
\text { result, in the form of products or services. }\end{array}$ \\
\hline $\begin{array}{l}\text { Simula, Hossain } \\
\text { and Halme (2015) }\end{array}$ & $\begin{array}{l}\text { Innovation that serves the needs of low-income clients, } \\
\text { typically located in emergent and low-income markets. }\end{array}$ & $\begin{array}{l}\text { - Scarcity of resources; } \\
\text { - Simplification; } \\
\text { - Lean and environmentally sustainable } \\
\text { practices. }\end{array}$ \\
\hline $\begin{array}{l}\text { Weyrauch and } \\
\text { Herstatt (2016) }\end{array}$ & $\begin{array}{l}\text { Frugal innovation characterized by three criteria (both } \\
\text { in emergent and developed markets). }\end{array}$ & $\begin{array}{l}\text { - Substantial cost reduction; } \\
\text { - Focus on basic functions; } \\
\text { - Optimized performance. }\end{array}$ \\
\hline
\end{tabular}

Source: Elaborated by the authors. 
The literature shows a variety of definitions for frugal innovation elaborated in recent years. The work by Pissoni, Michelini and Martignoni (2018), identified that the concept evolved in three lines. The first is the "product-oriented" line, which includes studies that emphasize products and services. The second is the market-oriented line, where studies on frugal innovation present variables beyond products and services. Finally, the third line gathers studies returning to the origins of the concept, identifying criteria that characterize frugal innovation (criteria-oriented definition).

The definitions or descriptions of frugal innovation in the literature, often concern the purchase price, or low-costs, consisting of characteristics of the concept. The terms that traditionally indicate these characteristics in the definitions observed in literature are reduced purchase price, low-cost products, and services, premium prices, minimization of nonessential costs, and considerably lower upfront costs (AGARWAL and BREM, 2012; BOUND and THORNTON, 2012; DOZ and WILSON, 2012; ECONOMIST, 2010; RADJOU and PRABHU, 2015; ZESCHKY, WIDENMAYER and GASSMANN, 2011). In other words, the cost dimension is almost unanimous in all works on frugal innovation. In the definition of Tiwari and Herstatt (2012), the price is an aspect evidenced, more specifically, in the characteristics 'accessibility' and 'attractive value proposition.' The same is observed in the study by the same authors in 2014 (TIWARI and HERSTATT, 2014) and by Tiwari, Fisher and Kalogerakis (2016). In the study by Weyrauch and Herstatt (2016), the issue of price was treated as 'substantial reduction' and 'cost limitation,' characterizing as a central element of Frugal Innovation.

Another aspect of the definition of frugal innovation supported in the literature is a dimension of reduced functionalities and unnecessary features (CHRISTENSEN, 1997; PRAHALAD, 2010; AGARWAL and BREM, 2012; BASU, BANERJEE and SWEENY, 2013; BHATTI, 2012; BOUND and THORNTON, 2012; BREM and IVENS, 2013; CUNHA, REGO, OLIVEIRA et al., 2014; THE ECONOMIST, 2010; RADJOU, PRABHU and AHUJA, 2012; SONI and KRISHNAN, 2014; TIWARI and HERSTATT, 2012; TIWARI, KALOGERAKIS and HERSTATT, 2016; ZESCHKY, WINTERHALTER and GASSMANN, 2014). Within this dimension called concentration on core functionalities, the study by Weyrauch and Herstatt (2016, p. 6) defines the attributes: "functional and focused on essentials," "minimizing the use of the material and financial resources," and "user-friendly and easy to use."

The literature also showed that the ecological comprehension is an important attribute of frugal innovation (GUPTA and WANG 2009; HOWARD 2011), given that the notion of frugality implies a concern for the environment and sustainability. Thus, this attribute should be considered in the definition, even though the results of the study by Weyrauch and Herstatt (2016) suggests that frugal innovation does not necessarily involve sustainability. For Sharma and lyer (2012), however, frugal innovations can contribute to sustainability by minimizing the use of resources. Also, the study by Tiwari, Kalogerakis and Herstatt (2016) indicates that a growing body of literature reveals that frugal innovations are ready to take on a more significant role in the future by offering a measure against unnecessary technological complexity, reducing the use of the precious resource. On the other hand, there is a sustainability component embedded in frugal innovations that characterizes them as "responsible innovations" (TIWARI, KALOGERAKIS and HERSTATT, 2016), although, as mentioned before, it is understood that sustainability is not always the focus of frugal innovation. The study by Silva (2018) emphasizes that frugal innovations are not limited to offering products and services at an affordable price, but should also be oriented towards sustainability, and the use of internal or external technologies and knowledge that lead to reducing the cost of innovation and production of processes and products.

Finally, according to Weyrauch and Herstatt (2016), another dimension that should be present simultaneously in the definition is that of optimized performance, considering a broad meaning for performance, encompassing all engineering features and characteristics, such as speed, power, durability, and accuracy.

The literature presented several understandings regarding the nature of the frugal process. It can be faced as a mentality, an outcome, and as a process. Soni and Krishnan (2014) note that the process is often referred to as frugal engineering, with frugal innovation being the outcome - an understanding shared by Brem and Wolfram (2014). In contrast, Basu, Banerjee and Sweeny (2013) understand frugal innovation as a complex process rather than just an outcome - as advocated by George, Mcgahan and Prabhu (2012).

The literature review suggested a link between the concepts of frugal innovation and bottom of the pyramid (BoP), disruptive innovation, and reverse innovation, as argued in the study by Tiwari, Fisher and Kalogerakis (2016). However, the phenomenon cannot be defined by any of these terms, since BoP, by definition, refers to the poor as target consumers 
and focuses largely on business-to-consumer (B2C) markets (PRAHALAD, 2010). Frugal innovations can target customers in any segment of the economic pyramid who are price-sensitive by choice or looking for "simpler" products that best meet their real needs. Customers can also demand these innovations in B2B (business-to-business) and B2C (business-toconsumer) segments due to price pressure or ecological conviction (TIWARI, FISHER and KALOGERAKIS, 2016). With regard to reverse innovation, related to products and services initially created in emerging economies for local markets but later are disseminated in the developed world (GOVINDARAJAN and TRIMBLE, 2012), there are examples of frugal innovations that occur in both the developed and developing worlds - with or without international dissemination (TIWARI, FISHER and KALOGERAKIS, 2016).

\section{Application and suggestions for future research}

The literature analyzed indicated that frugal innovation is a new and emerging field of research (TIWARI, KALOGERAKIS and HERSTATT, 2016) and showed that 2012 was the year when the publications on this topic reached a peak after years of slow growth (AGARWAL, GROTTKE, MISHRA et al., 2017; PISONI, MICHELINI and MARTIGNONI, 2018).

According to Pisoni, Michelini and Martignoni (2018), the growing importance of emerging markets stimulated stronger global competition, forcing changes in the strategies of multinational companies (BORINI, COSTA and MIRANDA, 2012; RAY and RAY, 2010). The authors emphasized that multinationals that focus on low-income markets need to rethink their innovation efforts to meet these public's "unconventional" demand (OJHA, 2014). In this case, authors such as Brem and Ivens (2013) adopt the concept of 'reverse innovation' to describe the phenomenon of change in the traditional origins and destinations of innovation.

For Mazieri (2016), structured innovations were created in parent multinational companies in developed countries and then sent to emerging countries to be applied by subsidiaries. However, the most recent literature recognizes that multinationals are not interested in subsidiaries that limit their activities in the production chain, adapting and selling products, and there is a crescent attention toward technological knowledge and innovation (BEZERRA and BORINI, 2015; BORINI, COSTA and OLIVEIRA JUNIOR, 2016; PISONI, MICHELINI and MARTIGNONI, 2018). In the study by Pisoni, Michelini and Martignoni (2018), several scholars highlighted the need to leverage technological knowledge in different locations (connecting and mobilizing innovation developed by subsidiaries) as a key factor in helping multinationals to improve in terms of sustainable competitiveness (BEZERRA and BORINI, 2015; BORINI, OLIVEIRA JUNIOR, SILVEIRA et al., 2012; BORINI, COSTA and OLIVEIRA JUNIOR, 2016). In this sense, the potential for reverse innovations, that is, those designed by subsidiaries and absorbed and used by the parent organization, is reflected in rethinking the innovation architecture implemented by multinationals in their global structures and strategies (RAY and RAY, 2010; BORINI, OLIVEIRA JUNIOR, SILVEIRA et al., 2012; OJHA, 2014).

Thus, the study by Pisoni, Michelini and Martignoni (2018) showed that technology transfer travels in non-traditional directions, from developing to developed countries, and from subsidiaries to parent companies (BORINI, OLIVEIRA JUNIOR, SILVEIRA et al., 2012; BORINI, COSTA and OLIVEIRA JUNIOR, 2016). Mazieri (2016) expresses the term 'open innovation' proposed by Chesbrough and states the need for cooperation and relationships with entities outside the company. The author emphasizes that frugal innovation, as a form of response to a constricted context, does not depend on a direction (it may be reverse innovation) and does not depend on format either. For the author, it may be an open innovation.

Another finding from the study by Pisoni, Michelini and Martignoni (2018) is the existence of at least three types of organizations when applying a frugal approach to innovation: local/micro-enterprises, small and medium enterprises, and multinational enterprises. The role played by small and medium-sized enterprises and local businesses in supporting frugal innovation is portrayed in the literature from a perspective of how multinationals implement and benefit from adopting the economic approaches to innovation that they find in the example of the smaller companies in emerging and developing countries (RAY and RAY, 2010). Pisoni, Michelini and Martignoni (2018) reinforce the importance of recognizing innovation in small and medium enterprises and startups in this research field focused on emerging countries. The authors point out the various particularities of the context around such organizations as well as the barriers to innovation they encounter in their development process. It is also important to note that there are unique characteristics of small businesses that offer a new context for the analysis of frugal innovation. Prabhu and Jain (2015) include in this discussion the social enterprises, which have passion, commitment, patience, and local knowledge, although they sometimes lack the ability to scale their solutions. Small and medium-sized enterprises (SMEs) are key to promoting economic growth, creating jobs, income, and improving the 
populations' living conditions. According to data provided by the Brazilian Institute of Geography and Statistics (IBGE), about 9 million SMEs, which represent $27 \%$ of Brazil's GDP, are responsible for employing 52\% of the country's formal labor force and paying $40 \%$ of the salaries (SEBRAE, 2014). Such data demonstrate its significant participation in the national economy. However, most small businesses have limited financial resources, experience, and time, making it difficult to attract customers and resources needed for innovation, which would contribute to generating revenue (AGBEIBOR JUNIOR, 2006). The study on frugal innovation in this context would be beneficial to unlock innovation in these organizations. Ling, Simsek, Lubatkin et al. (2008) also reinforce that SMEs have more significant restrictions in decision-making when compared to large organizations. The authors found that frugal approaches to innovation were identified primarily in resource-constrained environments, emerging and developing countries, and BoP contexts, where the ecosystem plays a crucial role (PISONI, MICHELINI and MARTIGNONI, 2018).

Despite the growing number of articles published on frugal innovation, there is a lack of instruments for measuring this phenomenon and enabling more accurate and quantifiable studies. Increasing interest in the construct has encouraged researchers to look into the concept (AGARWAL and BREAM, 2012; BHATTI, 2012; ECONOMIST, 2009; RAO, 2013; SONI and KRISHNAN, 2014; TIWARI, FISCHER and KALOGERAKIS, 2016; TIWARI, KALOGERAKIS and HERSTATT 2016; WEYRAUCH and HERSTATT, 2016; ZESCHKY, WIDENMAYER and GASSMANN, 2011). Other studies have focused on the distinctive features and structures of frugal innovation (BASU, BANERJEE and SWEENY, 2013; BREM and WOLFRAM, 2014; CUNHA, REGO, OLIVEIRA et al., 2014; GOVINDARAJAN and TRIMBLE, 2012; PRAHALAD, 2010; RADJOU, PRABHU and AHUJA, 2012; RAO, 2013; TIWARI and HERSTATT, 2012; ZESCHKY, WINTERHALTER and GASSMANN, 2014). Finally, there are works dedicated to the elaboration of rules and principles for frugal innovation (KUMAR and PURANAM, 2012; PRAHALAD and MASHELKAR, 2010; RADJOU, PRABHU and AHUJA, 2012).

Measurement is a fundamental activity of science (DEVELLIS, 2012), crucial for scientific inquiring (TUCKER, VISWANATHAN and WALFORD, 2010). The measurement process enables confirming and comparing studies' results and, therefore, developing measurement tools for frugal innovation contributes to determine characteristics of groups of companies, measure the predisposition of organizations for frugal innovation, and compare scales produced in different contexts.

Bound and Thornton (2012) suggest many reasons for the developed world to embrace frugal innovation, which include a) slow growth in developed economies, increasing the demand for frugal innovation processes; b) environmental constraints, increasing demands for more frugal models of production and consumption; c) attention for rapidly aging societies, a phenomenon that requires entirely new approaches to health care; d) understanding that today's fastest-growing markets are in developing economies where there is a high demand for frugal products.

Rosca, Arnold and Bendul (2017) observed the existence of numerous scholars discussing the potential contributions of frugal innovation to various aspects of sustainability. Frugal innovations can contribute to sustainable development by giving developing communities greater ability to buy products that meet their needs, reducing the use of natural resources, and creating inclusive economic growth by involving local communities in the value chain (BAUD, 2016; KNORRINGA, PEŠA, LELIVELD et al., 2016). However, the current empirical studies have suggested that frugal innovations are not inherently sustainable (ROSCA, ARNOLD and BENDUL, 2017). In this regard, it is important to explore in-depth whether, how, and when frugal innovations can drive sustainable development, and individual research has several limitations that hinder a clear understanding of the role of frugal innovation in supporting sustainable development (ROSCA, ARNOLD and BENDUL, 2017).

For future research, it is suggested the development of measurement tools to assess frugal innovation, since there are no specific instruments in the literature. In addition, in line with the suggestions found in other studies, future research could focus on analyzing aspects of the ecosystem; how to promote collaboration between the different actors involved in the frugal innovation process; and how to learn from community involvement. Future studies could also explore how to disseminate and market strategies for frugal innovation (PISONI, MICHELINI and MARTIGNONI, 2018). Finally, as suggested by Knorringa, Peša, Leliveld et al. (2016), more empirical studies are crucial to advance in the debates on frugal innovation.

One of the main objectives of empirical studies should be to look at frugal innovation through the lens of local economic development and, at the same time, establish connections between local processes and national and global contexts. Such empirical studies can generate better insights into the actors involved in frugal innovation, both locally and internationally (KNORRINGA, PEŠA, LELIVELD et al., 2016). Hossain and Simula (2013) also suggest the study of how opportunities and 
threats to innovation differ between developing and developed countries. The study by Simula, Hossain and Halme (2015, p. 5) suggested relevant questions for future research. The authors point to the importance to understand:

1. How do frugal innovations diffuse among low-income emerging markets and what kind of business models can support this? 2. How can firms from the low-income emerging markets enter the Western markets with reverse innovation? 3. What opportunities exist for Western firms to capture revenue from low-income emerging markets with frugal innovations? 4. How can Western firms build or restructure their business models and strategies to tap underserved and un-served customers with frugal innovations? 5. How can Western firms collaborate with local players in low-income emerging markets on frugal and reverse innovations? 6 . What are the barriers for reverse innovation to gain a foothold in developed markets?

\section{Box 2}

Synthesis of the application and suggestions for future research

\begin{tabular}{|c|c|}
\hline $\begin{array}{l}\text { Frugal innovation and } \\
\text { developed countries }\end{array}$ & $\begin{array}{l}\text { - Reverse flow of innovation projected in subsidiaries and absorbed by parent organizations; } \\
\text { - Flow of frugal innovation: from developing to developed countries; } \\
\text { - Growing importance of emerging markets, stimulating global competition and forcing } \\
\text { multinational companies to change their strategies; } \\
\text { - Environmental constraints promote frugal products and consumption in developed } \\
\text { economies. }\end{array}$ \\
\hline Frugal innovation and SMEs & $\begin{array}{l}\text { - Small and medium enterprises have the potential to act toward local solutions; } \\
\text { - Startups need to innovate with scarce and limited resources. }\end{array}$ \\
\hline $\begin{array}{l}\text { Frugal innovation and } \\
\text { sustainability }\end{array}$ & $\begin{array}{l}\text { - Frugal innovation has an environmental dimension; } \\
\text { - Frugal innovation potentially promote sustainable development; } \\
\text { - Innovations that reduce the use of natural resources. }\end{array}$ \\
\hline $\begin{array}{l}\text { Frugal innovation and local } \\
\text { development }\end{array}$ & $\begin{array}{l}\text { - Innovation and community engagement in the value chain. } \\
\text { - Frugal innovation in social enterprises and nonprofit organizations that are passionate and } \\
\text { committed to local issues; } \\
\text { - Collaboration among different actors involved in the process of frugal innovation and, } \\
\text { specifically, involved in learning from community engagement; } \\
\text { - Relating local processes with local, national, and global processes. }\end{array}$ \\
\hline $\begin{array}{l}\text { Frugal innovation } \\
\text { measurement }\end{array}$ & $\begin{array}{l}\text { - Need for more precise and quantifiable measurement; } \\
\text { - Development and validation of new measurement scales; } \\
\text { - Comparison among scales produced in different contexts to achieve conceptual evolution. }\end{array}$ \\
\hline
\end{tabular}

Source: Elaborated by the authors.

\section{CONCLUSION}

This theoretical essay presents the origin and evolution of the concept of frugal innovation, discussing the literature supporting its characteristics, reinforcing its importance and application and, finally, offering suggestions for future research. The study conducted a literature review analyzing the theoretical production, establishing connections, highlighting ideas, methods, and subthemes that have received more or less emphasis over time (VOSGERAU and ROMANOWSKI, 2014). For Rother (2007), the main objective of this type of review is the knowledge acquisition and updating about a specific theme, without establishing a methodology to reproduce and treat the data collected. According to Bernardo, Nobre and Jatene (2004), this type of review is based on the author's opinion, who decides which information is most relevant, without explaining how it is obtained, thus interfering with his subjective perception. 
According to the findings in this research, frugal innovation involves the design of solutions for the low-income market segments, i.e., the base of the pyramid (BoP). However, these innovations can be used in other economic segments, both in developing and developed countries. Organizations in emerging markets face strong resource constraints and develop the capacity to create valuable product solutions by replacing capital elements with low-cost local labor (RAY and RAY, 2010; DAWAR and CHATTOPADHYAY, 2002). However, the growing scarcity of resources is also an issue of developed markets, which increases the relevance of further investigation of such capacities (BREM and WOLFRAM, 2014). It is also important to remember that the ability to develop frugal innovation is a prerequisite for reverse innovation (ZESCHKY, WINTERHALTER and GASSMANN, 2014). This means that if frugal innovation is appropriately adopted and applied, it can become an advantage for the organization in any market or industry, enabling companies to achieve many benefits (ROSSETTI, BORINI and FRANKWIN, 2018).

Regarding the historical evolution of the concept, its origins, and definitions, it appears that the heterogeneous perspectives of the authors are gradually moving toward a convergent understanding of the main characteristics of frugal innovation. As observed by Pisoni, Michelini and Martignoni (2018), frugal innovation should be considered as an approach that involves the whole process of innovation, or product/service characteristics, rather than a specific form of innovation. When considered as an approach, frugal innovation may be "adaptable" and "transferable" to any industrial and territorial context, which is aligned with the latest definitions where frugal innovations aim to "create attractive value propositions for their target customer groups by focusing on core functionalities and thus minimizing the use of material and financial resources in the complete value chain" (TIWARI, FISCHER and KALOGERAKIS, 2016, p. 17; MICHELINI, PISONI and MARTIGNONI, 2018).

This work offers subsidies to suggest areas for future research on the theme. It also demonstrates the evolution and growth of the importance and application of this approach of innovation in the literature. In this sense, empirical research is fundamental, which enriches the current debates on frugal innovation, especially from the perspective of local economic development, through financial results and economic returns. At the same time, such studies work to connect local processes to the national and global contexts, leading to a better understanding of which actors are involved in the approach. Finally, this research is aligned with the suggestions observed in other works (BREM, 2017; HOSSAIN, 2017; PISONI, MICHELINI and MARTIGNONI, 2018; ROSSETTO, BORINI and FRANKWICK, 2018), advocating for the development of measurement tools for frugal innovation. 


\section{REFERENCES}

AGARWAL, N.; BREM, A. Frugal and reverse innovation - Literature overview and case study insights from a German MNC in India and China. In: INTERNATIONAL CONFERENCE ON ENGINEERING, TECHNOLOGY AND INNOVATION, 18., 2012, Munich. Proceedings... Munich: ICE, 2012. p. 1-11.

AGARWAL, N. et al. A Systematic Literature Review of ConstraintBased Innovations: State of the Art and Future Perspectives. IEEE Transactions on Engineering Management, v. 64, n.1, p. 3-15, 2017.

AGBEIBOR JUNIOR, W. Pro-poor economic growth: role of small and medium sized enterprises. Journal of Asian Economics, v. 17, n. 1, p. 35-40, 2006.

BASU, R. R.; BANERJEE, P. M.; SWEENY, E. G. Frugal Innovation: Core Competencies to address Global Sustainability. Journal of Management for Global Sustainability, v. 1, n. 2, p. 63-82, 2013.

BAUD, I. Moving towards inclusive development? Recent views on inequalities, frugal innovations, urban geo-technologies, gender and hybrid governance. The European Journal of Development Research, v. 28 , n. 2, p. 119-129, 2016.

BIRTCHNELL, T. Jugaad as systemic risk and disruptive innovation in India. Contemp. South Asia, v. 19, n. 4, p. 357-372, 2011.

BEZERRA, M. A.; BORINI, F. M. The impact of social and relational contexts on innovation transfer in foreign subsidiaries. International Journal of Learning Intellectual Capital, v.12, n. 1, p. 6-31, 2015.

BHATTI, Y. What Is Frugal, What Is Innovation? Towards a Theory of Frugal Innovation. SSRN Electronic Journal, Feb. 2012. Available at: <https://ssrn.com/abstract=2005910>. Accessed on: Nov. 10, 2017.

BHATTI, Y. A.; VENTRESCA, M. How can 'Frugal Innovation' be conceptualized? SSRN Electronic Journal, Jan. 2013. Available at: <http://ssrn.com/abstract=2203552>. Accessed on: Aug. 21, 2019.

BOBEL, I. Jugaad: A New Innovation Mindset. Journal of Business Financial Affairs, v. 1, n. 4, 2012. Available at: < http://doi. org/10.4172/2167-0234.1000e116>. Accessed on: Aug. 21, 2019.

BORINI, F. M.; COSTA, S.; OLIVEIRA JUNIOR, M. Reverse innovation antecedents. International Journal of Emerging Markets, v. 11, n. 2, p. 175-189, 2016.

BORINI, F. M. et al. The reverse transfer of innovation of foreign subsidiaries of Brazilian multinationals. European Management Journal, v. 30, n. 3, p. 219-231, 2012.

BOUND, K.; THORNTON, I. W. Our Frugal Future: Lessons from India's Innovation System. London: Nesta, 2012.

BREM, A. Frugal innovation-past, present, and future. IEEE Engineering Management Review, v. 45, n. 3, p. 37-41, 2017.

BREM, A.; IVENS, B. S. Do Frugal and Reverse Innovation Foster Sustainability? Introduction of a Conceptual Framework. Journal of Technology Management for Growing Economies, v. 4, n. 2, p. 31-50, 2013.

BREM, A.; WOLFRAM, P. Research and development from the bottom up-introduction of terminologies for new product development in emerging markets. Journal of Innovation Entrepreneurship, v. 3, n. 1, p. 1-22, 2014.
CHANDY, R. et al. From Invention to Innovation: Conversion Ability in Product Development. Journal of Marketing Research, v. 43, n. 3, p. 494-508, 2006.

CHATAWAY, J.; HANLIN, R.; KAPLINSKY, R. Inclusive Innovation: an Architecture for Policy Development. Innovation and Development, v. 4, n. 1, p. 33-54, 2014.

CHRISTENSEN, C. M. et al. Disruptive innovation for social change. Harvard Business Review, v. 84, n. 12, p. 94-101, 2006.

CHRISTENSEN, C. M.; SCOTT, D.; ERIK, A. Seeing what's next. Boston: Harvard Business School Publishing Corporation, 2004.

CHRISTENSEN, C. M. The innovator's dilemma: When New Technologies Cause Great Firms to Fail. Cambridge: Harvard Business School Publishing Corporation, 1997.

CRISP, L. N. Mutual learning and reverse innovation - where next? Globalization and Health, v. 10, n. 14, 2014.

CROSSAN, M. M.; APAYDIN, M. A Multi-Dimensional Framework of Organizational Innovation: A Systematic Review of the Literature. Journal of Management Studies, v. 47, n. 6, p. 1154-1191, 2010.

CUNHA, M. P. et al. Product innovation in resource-poor environments: three research streams. Journal of Product Innovation Management, v. 31, n. 2, p. 202-210, 2014.

DAWAR, N.; CHATTOPADHYAY, A. Rethinking marketing programs for emerging markets. Long Range Planning, v. 35, n. 5, p. 457-474, 2002.

DEVELLIS, R. F. Scale development: theory and applications. 3. ed. Beverly Hills: Sage Publications, 2012.

DOZ, Y. L., WILSON, K. Managing Global Innovation: Frameworks for Integrating Capabilities Around the World. Boston: Harvard Business School Press, 2012.

FU, X.; GONG, Y. Indigenous and foreign innovation efforts and drivers of technological upgrading: evidence from China. World development, v. 39. n. 7. p. 1213-1225. 2011.

GEORGE, G.; MCGAHAN, A. M.; PRABHU, J. Innovation for Inclusive Growth: Towards a Theoretical Framework and a Research Agenda. Journal of Management Studies, v. 49, n. 4, p. 661-683, 2012.

GOVINDARAJAN, V.; TRIMBLE, C. Organizational DNA for Strategic Innovation. California Management Review, v. 47, n. 3, p. 47-76, 2005.

GOVINDARAJAN, V.; TRIMBLE, C. Reverse Innovation - Is It In Your Strategic plan? Ontario: Leadership Excellence, 2012.

GOVINDARAJAN, V.; TRIMBLE, C. Reverse innovation: a global growth strategy that could pre-empt disruption at home. Strategy \& Leadership, v. 40, n. 5, p. 5-11, 2012 a.

GOVINDARAJAN, V.; TRIMBLE, C. Reverse innovation: Create far from home, win everywhere. Massachusetts: Harvard Business School Press, 2012b.

GOVINDARAJAN, V.; RAMAMURTI, R. Reverse innovation, emerging markets, and global strategy. Global Strategy Journal, v. 1, n. 3/4, p. 191-205, 2011. 
GULATI, R. Management lessons from the edge. Academy of Management Perspectives, v. 24, n. 2, p. 25-28, 2010.

GUPTA, V. An inquiry into the characteristics of entrepreneurship in India. Journal of International Business Research, v. 7, n. S1, p. 53-69, 2008.

GUPTA, A. K. Science, sustainability and social purpose: barriers to effective articulation, dialogue and utilization of formal and informal science in public policy. Massachusetts: Harvard Kennedy School, 1999. Available at: <http://www.hks.harvard.edu/sustsci/ists/TWAS_0202/ gupta_300199.pdf>. Accessed on: May 21, 2012.

GUPTA, V. Corporate response to global financial crisis: a knowledgebased model. Global Economy Journal, v. 11, n. 2, p. 1-15, 2011.

GUPTA A. K; WANG H. Getting China and India right. San Francisco: Jossey-Bass/Wiley; 2009.

HARTLEY, J. New development: Eight and a half propositions to stimulate frugal innovation in public services. Public Money \& Management, v. 34, n. 3, p. 227-232, 2014.

HOSSAIN, M. Mapping the frugal innovation phenomenon. Technology in Society, v. 51, p. 199-208, Nov. 2017. Available at: <https://doi. org/10.1016/j.techsoc.2017.09.006>. Accessed on: Aug. 21, 2019.

HOSSAIN, M; SIMULA, H. Frugal innovation and reverse innovation: imperative in the global business. In: BRITISH ACADEMY OF MANAGEMENT CONFERENCE, 27., 2013, Liverpool. Proceedings... Liverpool: BAM, 2013.

HOWARD, M. Will frugal innovation challenge the west? Market Leader, London, Quarter 3, p. 53, June 2011.

IMMELT, J. R.; GOVINDARAJAN, V.; TRIMBLE, C. How GE is disrupting itself. Harvard Business Review, v. 87, n. 10, p. 56-65, 2009.

KNORRINGA, P. et al. Frugal innovation and development: Aides or adversaries? The European Journal of Development Research, v. 28, n. 2, p. 143-153, 2016.

KRISHNAN, R. T. From Jugaad to Systematic Innovation: The Challenge for India. Bangalore: The Utpreraka Foundation, 2010.

KULANGARA, N. P.; JACKSON, S. A.; PRATER, E. Examining the impact of socialization and information sharing and the mediating effect of trust on innovation capability. International Journal of Operations \& Production Management, v. 36, n. 11, p. 1601-1624, 2016.

KUMAR, N., PURANAM, P. India inside: The emerging innovation challenge to the West. Boston: Harvard Business Press, 2012.

LAFLEY, A. G.; CHARAM, R. The Game Changer: How you can dribble revenue and profit growth with innovation. New York: Crown Publishing, 2008.

LING, Y. et al. The impact of transformational CEOs on the performance of small- to medium-sized firms: does organizational context matter? Journal of Applied Psychology, v. 93, n. 4, p. 923-934, 2008.

MAZIERI, M. R. Patentes e Inovação Frugal em uma perspectiva contributiva. 371p. Doctoral Dissertation (Doctor Degree in Administration) - Programa de Pós-Graduação em Administração, Universidade Nove de Julho, São Paulo, 2016.

MAZIERI, M. R; SANTOS, A. M.; QUONIAM, L. Inovação a partir das informações de patentes: Proposição de Modelo Open Source de
Extração de Informações de Patentes (crawler). In: SEMINÁRIOS EM ADMINISTRAÇÃO, 17., 2014, São Paulo. Anais... São Paulo: FEA USP, 2014. Available at: <http://sistema.semead.com.br/17semead/ resultado/trabalhosPDF/712.pdf>. Accessed on: Aug. 21, 2019.

MERRIAM WEBSTER. Frugal. 2015. Available at: <http://www.merriamwebster.com/dictionary/frugal>. Accessed on: Nov. 14, 2017.

NOBRE, M. R. C.; BERNARDO, W. M., JATENE, F. B. A prática clínica baseada em evidências: parte III Avaliação crítica das informações de pesquisas clínicas. Revista da Associação Médica Brasileira, São Paulo, v. 50, n. 2, p. 221-228, 2004.

NUNES P. F.; BREENE T. S Jumping the S-curve: how to beat the growth cycle, get on top, and stay there. Harvard: Harvard Business Review Press, 2011.

OJHA, A. K. MNCs in India: focus on frugal innovation. Journal of Indian Business Research, v. 6, n. 1, p. 4-28, 2014.

OSTRASZEWSKA, Z.; TYLEC, A. Reverse innovation - How it works. International Journal of Business and Management, v. 3, n. 1, p. 57-74, 2015.

PAWLOWSKI, J. M. Towards Born-Global Innovation: The Role of Knowledge Management and Social Software. In: EUROPEAN CONFERENCE ON KNOWLEDGE MANAGEMENT, 14., 2013, Kauna. Proceedings... Kauna: Academic Conferences and Publishing International Limited, 2013.

PISSONI, A.; MICHELINI, L.; MARTIGNONI, G. Frugal approach to innovation: state of the art and future perspectives. Journal of Cleaner Production, v. 171, p. 107-126, 2018.

PRABHU, G. N.; GUPTA, S. Heuristics of Frugal Service Innovations. In: PORTLAND INTERNATIONAL CONFERENCE OF MANAGEMENT OF ENGINEERING AND TECHNOLOGY, 2014, Portland. Proceedings... Portland: PICMET, 2014. p. 3309-3312.

PRABHU, J.; JAIN, S. Innovation and entrepreneurship in India: Understanding jugaad. Asia Pacific Journal of Management, v. 32, n. 4 , p. 843-868, 2015.

PRAHALAD, C. K.; MASHELKAR, R.A. Innovation's Holy Grail. Harvard Business Review, v. 88, p. 132-141, July/Aug. 2010.

PRAHALAD, C. K. The fortune at the bottom of the pyramid: Eradicating poverty through profits. New Jersey: Prentice Hall, 2010.

PRATHAP, G. The myth of frugal innovation in India. Current Science, v. 106, n. 3, p. 374-377, 2014

RADJOU, N.; PRABHU, J.; AHUJA, S. Jugaad Innovation: Think Frugal, Be Flexible, Generate Breakthrough Growth. San Francisco: JosseyBass, 2012.

RADJOU, N.; PRABHU, J. Frugal Innovation: How to Do More with Less. London: Profile Books, 2014.

RADJOU, N.; PRABHU, J. Frugal Innovation: How to do More with Less. New York: PublicAffairs, 2015.

RAMAMURTI, R. Competing with Emerging Market Multinationals. Business Horizons, v. 55, n. 3, p. 241-249, May/June 2012.

RAMDORAI, A.; HERSTATT, C. Frugal Innovation in Healthcare: How Targeting Low-Income Markets Leads to Disruptive Innovation. Heidelberg: Springer, 2015. 
RAO, B. C. How disruptive is frugal? Technology in Society, v. 35, n. 1, p. 65-73, fev. 2013.

RAY, P. K.; RAY, S. Resource-Constrained Innovation for Emerging Economies: The Case of the Indian Telecommunications Industry. IEEE Transactions on Engineering Management, v. 57, n. 1, p. 144 156, Feb. 2010.

REENA, J. India's next global export: innovation. BusinessWeek.com, New York, p. 1-3, 13 Mar. 2009.

ROSCA, E.; ARNOLD, M.; BENDUL, J. C. Business models for sustainable innovation - an empirical analysis of frugal products and services. Journal of Cleaner Production, v. 162, n. 20, p. S133-S145, 2017.

ROSSETTO, D. E.; BORINI, F. M.; FRANKWICK, G. L. A new scale proposition for measuring Frugal Innovation: scale development process and validation. In: SIMPÓSIO DE GESTÃO DA INOVAÇÃO TECNOLÓGICA, 30., 2018, Porto Alegre. Anais... Porto Alegre: ANPAD, 2018. p. 26-28.

ROTHER, E. T. Revisão sistemática x revisão narrativa. Acta Paulista de Enfermagem, v. 20, n. 2, p. 2007.

SARAF, D. India's indigenous genius: Jugaad. The Wall Street Journal, 2009. Available at: <http://online.wsj.com/article/ SB124745880685131765.html>. Accessed on: Nov. 14, 2017.

SCHWAAG SERGER, S.; BREIDNE, M. China's fifteen-year plan for science and technology: an assessment. In: FAIR, C.; FRAZIER, MW. (Eds.). Asia Policy. Washington, DC: The National Bureau of Asian Research, 2007. p. 135-164. v. 4.

SHARMA, A.; IYER, G. R. Resource-constrained product development: implications for green marketing and green supply chains. Industrial Marketing Management, v. 41, n. 4, p. 599-608, 2012.

SILVA, I. M. Capacidades Organizacionais para a Inovação Frugal. 2018. 166 p. Doctoral Dissertation (Doctor Degree in Administration) - Programa de Pós-Graduação em Administração, Faculdade de Economia, Administração e Contabilidade, Universidade de São Paulo, São Paulo, 2018.

SIMULA, H.; HOSSAIN, M.; HALME, M. Frugal and reverse innovations - Quo Vadis? Current Science, v. 109, n. 5, p. 1567-1572, 2015.

SINGH, B. Concept of frugality and informal sector innovations in the context of local development. In: INTERNATIONAL CONFERENCE ON STRATEGIES IN VOLATILE AND UNCERTAIN ENVIRONMENT FOR EMERGING MARKETS, 2017, New Delhi. Proceedings... New Delhi: CONAL, 2017. p. 573-579.

SINGHAL, V. The impact of emerging economies innovative new models of global growth and vitality are emerging. Vision, v. 35, n. 2, p. 12-14, 2011.

SONI, P.; KRISHNAN, R.T. Frugal innovation: Aligning theory, practice, and public policy. Journal of Indian Business Research, v. 6, n. 1, p. 29-47, 2014.

THE ECONOMIST. First break all the rules: the charms of frugal innovation. London: The Economist, 2010. (Special report on innovation in emerging markets).

THE ECONOMIST. Burgeoning bourgeoisie. London: The Economist, 2009. (A special report on the new middle classes in emerging markets).
TIWARI, R.; HERSTATT, C. India - A Lead Market for Frugal Innovations? Extending the Lead Market Theory to Emerging Economies. Hamburg: Institute for Technology and Innovation Management, 2012. (Working paper, n. 67).

TIWARI, R.; HERSTATT, C. Assessing India's lead market potential for cost-effective innovations. Journal of Indian Business Research, v. 4, p. 97-115, 2013.

TIWARI, R.; HERSTATT, C. Aiming Big with Small Cars: Emergence of a Lead Market in India. Heidelberg: Springer, 2014.

TIWARI, R.; FISCHER, L.; KALOGERAKIS, K. Frugal Innovation in Scholarly and Social Discourse: An Assessment of Trends and Potential Societal Implications. Leipzig/Hamburg: Fraunhofer MOEZ Leipzig; Hamburg University of Technology, 2016. (Working paper, n. 189/ WEP 2-22).

TIWARI, R.; KALOGERAKIS, K.; HERSTATT, C. Frugal innovations in the mirror of scholarly discourse: Tracing theoretical basis and antecedents. In: R\&D MANAGEMENT CONFERENCE, 2016, Cambridge. Proceedings... Cambridge: RND, 2016.

THOMPSON, V. A. Bureaucracy and innovation. Administrative Science Quarterly, v. 10, n. 1, p. 1-20, 1965.

TUCKER, E.; VISWANATHAN, M.; WALFORD, G. Reflections on Social Measurement: How Social Scientists Generate, Modify, and Validate Indicators and Scales. In: TUCKER, E.; VISWANATHAN, M.; WALFORD, G. (Eds.). The SAGE Handbook of Measurement. London: SAGE, 2010. p. 1-7. v. 1.

VON KROGH G.; RAISCH, S. Focus Intensely on a Few Great Innovation Ideas. Harvard Business Review, Oct. 2009.

VOSGERAU, D. S. R.; ROMANOWSKI, J. P. Estudos de revisão: implicações conceituais e metodológicas. Revista Diálogo Educacional, Curitiba, v. 14, n. 41, p. 165-189, Jan./Apr. 2014.

WANG, C. et al. Exploring the role of government involvement in outward FDI from emerging economies. Journal of International Business Studies, v. 43, n. 7, p. 655-676, 2012.

WANG, X.; DASS, M. Building innovation capability: The role of top management innovativeness and relative-exploration orientation. Journal of Business Research, v. 76, p. 127-135, 2017.

WEYRAUCH, T.; HERSTATT, C. What is frugal innovation? Three defining criteria. Journal of Frugal Innovation, v. 2, n. 1, 2016.

WILLIAMS, C.; VAN TRIEST, S. The impact of corporate and national cultures on decentralization in multinational corporations. International Business Review, v. 18, n. 2, p. 156-167, 2009.

WOOLDRIDGE, A. The World Turned Upside Down. London: The Economist, 2010. (A Special Report on Innovation in Emerging Markets).

ZESCHKY, M.; WIDENMAYER, B.; GASSMANN, O. Frugal Innovation in Emerging Markets: The Case of Mettler Toledo. Research-Technology Management, v. 54, n. 4, p. 38-45, 2011.

ZESCHKY, M.; WINTERHALTER, S.; GASSMANN, O. From Cost to Frugal and Reverse Innovation: Mapping the Field and Implications for Global Competitiveness. Research-Technology Management, v. 57, n. 4 , p. $20-27,2014$ 
Graziele Ventura Koerich

ORCID: https://orcid.org/0000-0001-7595-1714

PhD student of Administration at the School of Administration and Socio-Economic Sciences of the Santa Catarina State University (ESAG/UDESC); Civil servant working at the Federal University of Santa Catarina (UFSC), Florianópolis - SC, Brazil. E-mail: grazi.koerich@hotmail.com

Éverton Luis. Pellizzaro de Lorenzi Cancellier

ORCID: https://orcid.org/0000-0002-2634-4763

Associate Professor of the School of Administration and Socio-Economic Sciences of the Santa Catarina State University (ESAG/UDESC), Florianópolis SC, Brazil. E-mail: everton.cancellier@udesc.br

\section{Cad. EBAPE.BR, v. 17, nº 4, Rio de Janeiro, Oct./Dec. 2019.}

